\title{
FAKTOR-FAKTOR YANG BERHUBUNGAN DENGAN PENCAPAIAN PROGRAM PROMOTIF PEMBERIAN ASI EKSKLUSIF DI UNIT PELAKSANA TEKNIS PUSKESMAS DARUSSALAM MEDAN
}

\author{
Fithri Ananda1, Ermi Girsang ${ }^{2}$, Masryna Siagian³
}

Kampus Universitas Prima Indonesia, Fakultas Kesehatan Masyarakat Jl. Anwar idris Tanjungbalai, Kecamatan Datuk Bandar Timur, Kelurahan Bunga Tanjung Sumatera Utara.

Email: anandafithri65@gmail.com

DOI : https://doi.org/10.35451/jkk.v2i1.225

\begin{abstract}
Exclusive breastfeeding means babies who are only breastfed from 0-6 months of age, without providing additional food or drinks. Infants aged 0-6 months are very vulnerable because the baby's digestive system is not functioning properly so that the baby has not been able to digest food or drinks other than breast milk. Breastfeeding for 6 months actually encourages optimal baby growth. However, currently exclusive breastfeeding in Indonesia is declining, one of which is in Medan, precisely in the Darussalam Health Center, Medan has not reached the target. The purpose of this study was to determine the factors associated with the achievement of an exclusive breastfeeding promotion program in Darussalam Medan Health Center. This type of research is descriptive with the Cross Sectional design approach. The population of this study were all mothers who had 0-6 months babies as many as 59 people. The sampling technique in this study is total sampling. study sample amounted to 59 people. The results of this study use the chi square test with a 95\% confidence level. The results refer that there was a relationship of knowledge, and attitudes with the low achievement of the promotion of exclusive breastfeeding programs with each $p$-value <of a $(0.033<0.05),(0.033<0.05)$, and there was no correlation about motherhood assigment and the performance of health workers with low achievement of exclusive breastfeeding promotive programs with each $p$-value $>$ of $a(0.197>0.05),(0.197>0.05)$. The conclusion is that there is a correlation between mother's knowledge and mother's attitude with the achievement of an exclusive breastfeeding promotion program.
\end{abstract}

Keywords: Achievement of an exclusive breastfeeding promotion program, Employment, Knowledge, Attitudes and Performance of health workers 


\section{PENDAhUlUan}

Menurut (PERMENKES RI, 2014) menyatakan penyediaan pelayanan kesehatan ialah tempat yang digunakan untuk pelaksanaan upaya promotif, preventif, kuratif maupun rehabilitatif yang dilakukan oleh pemerintah untuk masyarakat.

\section{World Health Organisation}

mengatakan merawat kesehatan bayi dan ibu merupakan langkah terbaik dalam pemberian ASI eksklusif sampai 6 bulan. (Khairiyah, 2013).

Tujuan utama pembangunan kesehatan ialah menurunkan angka kematian bayi untuk mencapai Sustainable Development Goals (SDGS). Dimana didapatkan angka kematian bayi tahun 2015 berjumlah 40 per 1000 kelahiran hidup dan masih menempati peringkat ke-4 tertinggi kematian bayi seASEAN. (Kementerian Kesehatan RI,2015)

Pelayanan Promotif merupakan upaya kesehatan masyarakat salah satunya ibu dan anak, akibat yang dapat terjadi apabila tidak melakukan upaya promotif seperti penurunan APBN dikarenakan semakin banyak rakyat yang sakit. (Dewi,dkk,2016).

Berdasarkan (PMK, 2013) pelayanan kesehatan tingkat pertama merupakan pelayanan kesehatan individu yang bersifat primer. terdapat empat fungsi pelayanan kesehatan tingkat pertama antara lain setiap pasien yang memiliki masalah kesehatan, hubungan pelayanan kesehatan tingkat pertama dengan pasien berjalan optimal, pelayanan kesehatan tingkat pertama memberikan pelayanan kesehatan yang komprehensif termasuk pelayanan promotif, dan pelayanan kesehatan tingkat pertama melaksanakan pelayanan dengan penyelenggara kesehatan lainnya (Dewi,dkk, 2016).

Menurut WHO (2012), dalam Anggraeni (2018), menunjukkan bahwa $65 \%$ populasi bayi didunia beumur kurang dari satu tahun atau berumur satu tahun, $35 \%$ bayi yang mendapatkan ASI eksklusif pada usia 0-4 bulan. Pada tahun 2012 UNICEF menyatakan bahwa 136,7 juta bayi lahir didunia hanya $32,6 \%$ yang mendapatkan ASI eksklusif sampai usia 6 bulan.
Berdasarkan data nasional tahun 2016 menunjukkan cakupan pemberian ASI eksklusif pada bayi usia kurang dari enam bulan sebesar $54,0 \%$ sudah mencapai target. Berdasarkan data provinsi, pemberian ASI eksklusif pada bayi berusia 0-5 bulan di Gorontalo mencapai $32,3 \%$ dan di Nusa Tenggara Timur mencapai 79,9\%. Dari 34 provinsi terdapat tiga provinsi yang masih belum mencapai target seperti Gorontalo, Riau dan Kalimantan Tengah (Profil Kesehatan Indonesia Tahun 2016).

Menurut hasil penelitian

Rumangun, dkk (2013) menunjukkan bahwa pencapaian program ASI eksklusif belum sesuai target nasional yakni masih dibawah $80 \%$ dikarenakan kurang tersedia sarana dan prasarana, dana, tenaga serta sosialisasi ASI eksklusif dipaketkan dengan sosialisasi kesehatan yang lainnya.

ASI Eksklusif di Indonesia masih belum mencapai target. Berdasarkan data (SDKI, 2013) ASI eksklusif mencapai $42 \%$. Sedangkan data dari dinas kesehatan provinsi tahun 2014, cakupan pemberian ASI 0-6 bulan mencapai 54,3\%, (Pusdatin,2015). pemberian ASI eksklusif bayi dibawah 6 bulan mencapai $41 \%$, dan bayi yang berumur 4-5 bulan mencapai $27 \%$, dan bayi menyusui sampai anak umur 2 tahun mencapai $27 \%$ (Kementerian Kesehatan RI,2015).

Berdasarkan Profil Kesehatan

Sumatera Utara (2016) persentase cakupan bayi yang mendapatkan ASI Eksklusif pada tahun 2016 terjadi penurunan yang tajam dibanding tahun 2015 dan tidak mencapai target nasional $<$ dari 40\%. Kabupaten/Kota dengan pencapaian $\geq 40 \%$ untuk Kabupaten yaitu Labuhan Batu Utara (97.90\%), Samosir (94.8\%), Humbang Hasundutan $(84.0 \%)$, Simalungun (60.6\%), Dairi (55.7\%), Pakpak Bharat (50.5\%), Deli Serdang $(47.1 \%)$, Asahan (43.6\%), Labuhan Batu (40.9\%) dan untuk Kota yaitu Gunung Sitoli $(84.5 \%)$, Sibolga (46.7\%). Enam puluh empat daerah dengan pencapaian < $10 \%$ yaitu Kota Medan (6.7\%) dan Tebing-Tinggi (7.4\%). ${ }^{(5)}$

Berdasarkan data Dinas kesehatan Sumatera Utara, persentase bayi yang mendapatkan ASI eksklusif dari tahun 2010-2014 menunjukkan peningkatan, 
dan cakupan pada tahun 2014 menyatakan masih belum mencapai target nasional, dan angka menyusui pada bayi kurang dari satu jam (IMD) di Sumatera Utara mencapai 22,9\%.

Berdasarkan data Dinas Kesehatan Medan pada bulan Agustus 2013 dari 39 Puskesmas yang ada di Medan terdapat $174(4,08 \%)$ bayi yang mendapat ASI eksklusif dan terdapat 4089 (95,9\%) bayi yang tidak mendapat ASI eksklusif sementara target yang harus dicapai ialah 80\% (Dinas Kesehatan Provinsi Sumatera Utara, 2013).

Hasil survei pendahuluan pada bulan Februari tahun 2018 yang di lakukan di Puskesmas Darussalam Medan tercatat pemberian ASI eksklusif pada bayi 0-6 bulan yaitu $22,2 \%$ dari Kelurahan Sei Sikambing D dan 55,6\% dari Sei Putih Barat dan total keseluruhan 38,9\% dan data pada bulan Agustus tahun 2018 tercatat pencapaian pemberian ASI eksklusif pada bayi 0-6 bulan di Kelurahan Sei Sikambing sebanyak 64,7\% dan di Sei Putih Barat $55,6 \%$ dengan total keseluruhan $61,5 \%$.

Berdasarkan latar belakang diatas, maka peneliti akan melakukan penelitian mengenai "Faktor-faktor yang berhubungan dengan pencapaian program promotif pemberian ASI eksklusif di Unit Pelaksana Teknis Puskesmas Darussalam Medan Tahun 2019".

\section{METODE PENELITIAN}

Jenis penelitian ini ialah deskriptif dengan menggunakan pendekatan desain Cross Sectional. Populasi penelitian ini merupakan ibu yang mempunyai bayi 0-6 bulan sebanyak 59 orang. Teknik pengambilan sampel pada penelitian ini adalah Total Sampling. Oleh karena itu populasi dianggap kecil atau kurang dari 100 , sehingga seluruh populasi penelitian menjadi sampel penelitian sebanyak 59 orang (Notoatmodjo, 2013).

\section{HASIL}

Adapun hasil penelitian ini sebagai berikut:

\section{Analisis Univariat}

Analisis

mengetahui distribusi frekuensi berdasarkan usia ibu, pendidikan terakhir ibu, pekerjaan ib, umur anak, jenis kelamin, anak ke, di Puskesmas Darussalam Medan Tahun 2019.

Tabel 1. Distribusi Berdasarkan usia ibu, pendidikan terakhir ibu, pekerjaan ibu, umur, jenis kelamin, anak ke, di Puskesmas Darussalam Medan Tahun 2019.

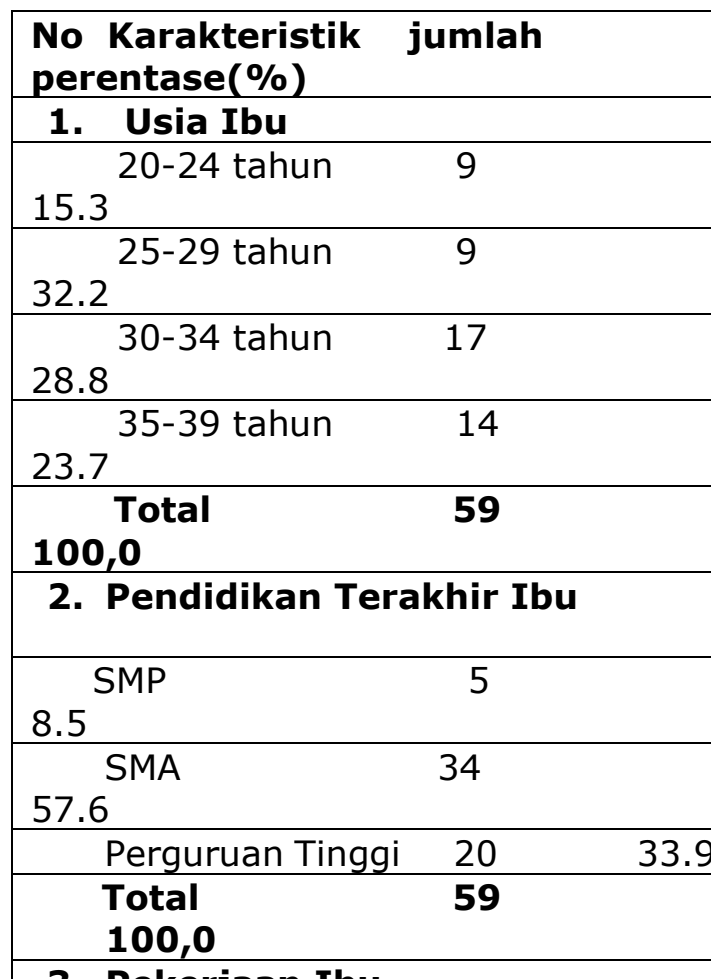

3. Pekerjaan Ibu

\begin{tabular}{|c|c|c|}
\hline $\begin{array}{l}\text { Pedagang } \\
15.3 \\
\end{array}$ & 9 & \\
\hline $\begin{array}{l}\text { Ibu Rumah Tangga } \\
59.3\end{array}$ & 35 & \\
\hline $\begin{array}{l}\text { Pegawai Swasta } \\
18.6\end{array}$ & 11 & \\
\hline $6.8^{\text {Pegawai Negeri }}$ & 4 & \\
\hline $\begin{array}{l}\text { Total } \\
100.0 \\
\end{array}$ & 59 & \\
\hline \multicolumn{3}{|l|}{ 4. Umur } \\
\hline$<3$ bulan & 5 & 8.5 \\
\hline$>3$ bulan & 54 & 91.5 \\
\hline Total & 59 & 100,0 \\
\hline \multicolumn{3}{|l|}{ 5. Jenis Kelamin } \\
\hline Laki-Laki & 35 & 59.3 \\
\hline 40.7 Perempuan & 24 & \\
\hline
\end{tabular}




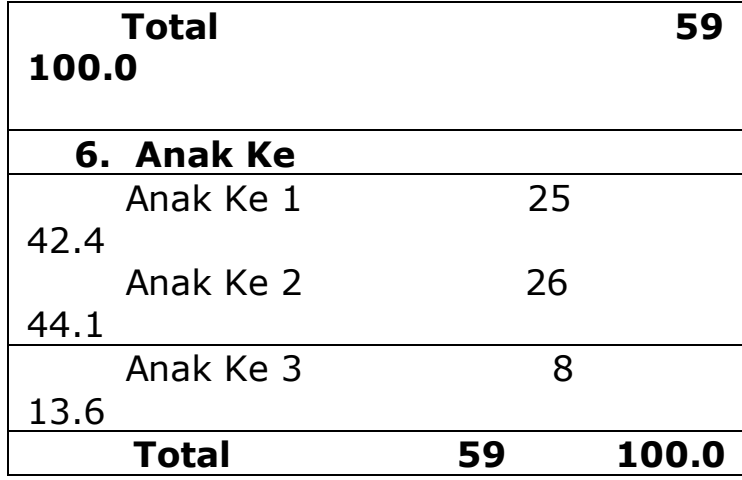

Berdasarkan tabel 1 diperoleh distribusi frekuensi kelompok usia responden, mayoritas responden kelompok usia 25-29 tahun sebanyak 19 orang responden $(32,2 \%)$ dan minioritas responden kelompok usia 20-24 tahun sebanyak 9 orang (15,3\%).

Berdasarkan pendidikan responden, mayoritas pendidikan SMA sebanyak 34 orang $(57,6 \%)$ dan minioritas berpendidikan SMP sebanyak 5 orang ( $8,5 \%)$.

Berdasarkan pekerjaan responden, mayoritas Ibu rumah tangga sebanyak 35 orang $(59,3 \%)$ dan minioritas pekerjaan Pegawai negeri sebanyak 4 orang $(6,8 \%)$.

Berdasarkan kelompok umur responden, mayoritas responden kelompok umur $>3$ bulan sebanyak 54 orang $(91,5 \%)$ dan minioritas kelompok umur $<3$ bulan sebanyak 5 orang $(8,5 \%)$.

Berdasarkan jenis kelamin dari 59 responden, mayoritas responden berjenis kelamin laki-laki sebanyak 35 orang $(59,3$ $\%$ dan minioritas berjenis kelamin perempuan sebanyak 24 orang $(40,7 \%)$.

Berdasarkan kelompok anak, responden anak ke 2 sebanyak 26 orang $(44,1 \%)$ dan mayoritas responden kelompok anak ke 3 sebanyak 8 orang $(13,6 \%)$.

Tabel 2. Distribusi Berdasarkan Pekerjaan ibu, Pengetahuan ibu, Sikap ibu, Kinerja Tenaga Kesehatan, dan program promotif pemberian ASI eksklusif Tahun 2019.

\begin{tabular}{|ll|}
\hline $\begin{array}{l}\text { No } \quad \text { Variabel } \\
\text { Persentase (\%) }\end{array}$ & Jumlah (n ) \\
\hline $1 \quad$ Pekerjaan Ibu \\
\hline $\begin{array}{l}\text { Bekerja } \\
76,3\end{array}$ \\
\hline
\end{tabular}

\begin{tabular}{|c|c|c|}
\hline \multicolumn{2}{|c|}{$\begin{array}{l}\text { Tidak bekerja } \\
23,7\end{array}$} & 14 \\
\hline \multicolumn{2}{|c|}{$\begin{array}{l}\text { Total } \\
100,0\end{array}$} & 59 \\
\hline \multicolumn{3}{|c|}{2 Pengetahuan Ibu } \\
\hline \multicolumn{2}{|c|}{$61.0^{\text {Tidak }}$} & 36 \\
\hline \multicolumn{2}{|c|}{$39.0^{Y a}$} & 23 \\
\hline \multicolumn{2}{|c|}{$\begin{array}{l}\text { Total } \\
100,0 \\
\end{array}$} & 59 \\
\hline \multicolumn{3}{|c|}{3 Sikap Ibu } \\
\hline \multirow{3}{*}{\multicolumn{2}{|c|}{$\begin{array}{l}\quad \text { Tidak } \\
61,0 \\
\quad \mathrm{Ya} \\
39.0 \\
\text { Total } \\
\mathbf{1 0 0 , 0}\end{array}$}} & 36 \\
\hline & & 23 \\
\hline & & 59 \\
\hline \multicolumn{3}{|c|}{4 Kinerja Tenaga Kesehatan } \\
\hline \multicolumn{2}{|c|}{$76,3^{Y a}$} & 45 \\
\hline \multicolumn{2}{|c|}{$\begin{array}{l}\text { Tidak } \\
23,7\end{array}$} & 14 \\
\hline \multirow{2}{*}{\multicolumn{3}{|c|}{$\begin{array}{l}\text { Total } \\
100,0 \\
\text { 5. Program Promotif Pemberian } \\
\text { ASIEkslusif }\end{array}$}} \\
\hline & & \\
\hline \multicolumn{2}{|c|}{$35.6^{\text {Baik }}$} & 21 \\
\hline & $\begin{array}{l}\text { Tidak baik } \\
64.4\end{array}$ & 38 \\
\hline & $\begin{array}{l}\text { Total } \\
, 0\end{array}$ & 59 \\
\hline
\end{tabular}

Berdasarkan tabel 2 pekerjaan ibu mayoritas responden menilai Program Promotif pemberian ASI eksklusif adalah baik yaitu sebanyak 45 orang $(76,3 \%)$ dan minoritas responden menilai Program Promotif pemberian ASI eksklusif adalah tidak baik sebanyak 14 orang $(23,7 \%)$.

Berdasarkan pengetahuan ibu, mayoritas responden menilai Program Promotif pemberian ASI eksklusif ialah tidak baik yaitu 36 orang $(61,0 \%)$ dan minoritas responden menilai Program Promotif pemberian ASI eksklusif adalah baik sebanyak 23 orang $(39,0 \%)$.

Berdasarkan Sikap ibu, mayoritas responden menilai Program Promotif pemberian ASI eksklusif adalah tidak baik sebanyak 36 orang $(61,0 \%)$ dan minoritas responden menilaiProgram Promotif pemberian ASI ekslusif adalah baik sebanyak 23 orang $(39,0 \%)$. 
Berdasarkan Kinerja Tenaga Kesehatan, mayoritas responden menilaiProgram Promotif pemberian ASI ekslusif ialah baik sebanyak 45 orang $(76,3 \%)$ dan minoritas responden menilai Program Promotif pemberian ASI ekslusif adalah tidak baik sebanyak 14 orang $(23,7 \%)$.

Berdasarkan tinjauan Program Promotif pemberian ASI eksklusif, mayoritas responden menilai Program Promotif pemberian ASI eksklusif ialah Tidak baik yaitu 38 orang $(64,4 \%)$ dan minioritas respondenProgram Promotif pemberian ASI ekslusif ialah baik sebanyak 21 orang $(35,6 \%)$.

\section{Analisis Bivariat}

Analisis bivariat bertujuan untuk mengetahui Faktor-faktor yang berhubungan dengan pencapaian Program Promotif pemberian ASI eksklusif di Unit Pelaksana Teknis Puskesmas Darussalam Medan 2019 terhadap 59 responden dengan menggunakan uji Chi Square, maka diperoleh hasil sebagai berikut :

Tabel 3.

Faktor-faktor

yang berhubungan dengan pencapaian program promotif pemberian ASI eksklusif Berdasarkan Pekerjaan Ibu di Puskesmas Darussalam Medan Tahun 2019.

Program Pemberian ASI Total

\begin{tabular}{lcccccc} 
Pekerjaan & Ya & \multicolumn{2}{c}{ Tidak } & & $\boldsymbol{p}$ \\
\hline value & $\mathrm{n}$ & $\%$ & $\mathrm{n}$ & $\%$ & $\mathrm{~N}$ & $\%$ \\
\hline $\begin{array}{l}\text { Ya } \\
100,0\end{array}$ & 14 & 31,1 & 31 & 68,9 & 45 \\
\hline 0197 & & & & & & \\
\hline $\begin{array}{l}\text { Tidak } \\
100,0\end{array}$ & 7 & 50,0 & 7 & 50,0 & 14 \\
\hline
\end{tabular}

Berdasarkan tabel 3 dapat diketahui dari 45 responden mayoritas yang menjawab pencapaian program promotif pemberian ASI eksklusif tidak baik tetapi menilai Pekerjaan ibu baik sebanyak 31 orang $(68,9 \%)$, dan minioritas yang menjawab pencapaian program promotif pemberian ASI eksklusif baik dan menilai hubungan pekerjaan ibu baik sebanyak 14 orang $(31,1 \%)$, dan dari 14 responden mayoritas yang menilai pencapaian program promotifpemberian ASI eksklusif tidak baik dan pekerjaan ibu tidak baik sebanyak 7 orang $(50,0 \%)$, dan minoritas yang menjawab pencapaian program promotifpemberian ASI eksklusif baik tetapi pekerjaan ibu tidak baik sebanyak 7 orang $(50,0 \%)$.

Tabel 4. Faktor-faktor berhubungan pencapaian promotif pemberian ASI eksklusif Berdasarkan Pengetahuan Ibu di Puskesmas Darussalam Medan Tahun 2019.

\begin{tabular}{|c|c|c|c|c|}
\hline \multicolumn{3}{|c|}{ Program Pemberian ASI } & \multicolumn{2}{|c|}{ Total } \\
\hline \multicolumn{5}{|c|}{$\begin{array}{l}\text { Pengetahuan } \\
\text { value }\end{array}$} \\
\hline & $\mathrm{n} \quad \%$ & $\mathrm{n} \%$ & $\mathrm{~N}$ & $\%$ \\
\hline $\begin{array}{l}\text { Ya } \\
100,0\end{array}$ & 925,0 & 2775,0 & 36 & \\
\hline \multicolumn{5}{|l|}{0,033} \\
\hline $\begin{array}{l}\text { Tidak } \\
100,0\end{array}$ & 1252,2 & 1147,8 & 23 & \\
\hline
\end{tabular}

Berdasarkan tabel 4 dari 36 responden mayoritas yang menjawab pencapaian program promotif pemberian ASI eksklusif tidak baik tetapi menilai Pengetahuan ibu baik sebanyak 27 orang $(75,0 \%)$, dan minioritas yang menjawab pencapaian program promotifpemberian ASI eksklusif baik dan menilai hubungan pengetahuan ibu baik sebanyak 9 orang $(25,0 \%)$, dan dari 9 orang responden mayoritas yang menilai pencapaian program promotifpemberian ASI eksklusif tidak baik dan pengetahuan ibu tidak baik sebanyak 12 orang $(52,2 \%)$, dan minoritas yang menjawabpencapaian program promotif pemberian ASI eksklusif baik tetapi pekerjaan ibu tidak baik sebanyak 11 orang $(47,8 \%)$.

Tabel 5. Faktor-faktor yang berhubungan dengan pencapaian program promotif pemberian ASI eksklusif Berdasarkan Sikap Ibu di Puskesmas Darussalam Medan Tahun 2019. 


\begin{tabular}{|c|c|c|c|c|c|}
\hline \multicolumn{6}{|c|}{$\begin{array}{l}\text { Program Pemberian ASI } \\
\text { Total }\end{array}$} \\
\hline \multirow[t]{2}{*}{$\begin{array}{l}\text { Sikap } \\
p \text { value }\end{array}$} & Ya & Tid & Jak & & \\
\hline & $\mathrm{n} \%$ & $\mathrm{n}$ & $\%$ & $\mathrm{~N}$ & $\%$ \\
\hline $\mathbf{Y a}$ & 925,0 & 27 & 75,0 & 36 & 100,0 \\
\hline \multicolumn{6}{|l|}{0,033} \\
\hline Tidak & 1252,2 & 11 & 47,8 & 23 & 100,0 \\
\hline
\end{tabular}

diketahui dari 36 responden mayoritas yang menjawab pencapaian program promotif pemberian ASI eksklusif tidak baik tetapi menilai sikap ibu baik sebanyak 27 orang $(75,0 \%)$, dan minioritas yang menjawabpencapaian program promotif pemberian ASI eksklusif baik dan menilai hubungan sikap ibu baik sebanyak 14 orang $(31,1 \%)$, dan dari 9 orang $(25,0 \%)$, dan dari responden mayoritas yang menilai pencapaian program promotifpemberian ASI eksklusif tidak baik dan sikap ibu tidak baik sebanyak 12 orang $(52,2 \%)$, dan minoritas yang menjawab pencapaian program promotifpemberian ASI eksklusif baik tetapi pekerjaan ibu tidak baik sebanyak 11 orang $(47,8 \%)$.

Tabel 6. yang berhubungan
pencapaian program promotif yang berhubungan dengan
pencapaian program promotif

Faktor-faktor pemberian ASI eksklusif Berdasarkan Kinerja Petugas Kesehatan di Puskesmas Darussalam Medan Tahun 2019.

\begin{tabular}{|c|c|c|c|c|}
\hline \multicolumn{2}{|c|}{$\begin{array}{l}\text { Program } \\
\text { Total }\end{array}$} & \multicolumn{2}{|c|}{ Pemberian } & ASI \\
\hline \multicolumn{5}{|c|}{ Kinerja } \\
\hline \multicolumn{2}{|c|}{$\begin{array}{l}\text { Kesehatan } \\
\text { value }\end{array}$} & \multicolumn{2}{|c|}{ Tidak } & $\boldsymbol{p}$ \\
\hline $\mathrm{n} \quad \%$ & $\mathrm{n} \quad \%$ & $\mathrm{~N}$ & $\%$ & \\
\hline $\begin{array}{l}\text { Ya } \\
100,0\end{array}$ & 14 & 31,1 & 3168,9 & 45 \\
\hline 0,197 & & & & \\
\hline $\begin{array}{l}\text { Tidak } \\
100,0\end{array}$ & 7 & 50,0 & 750,0 & 14 \\
\hline
\end{tabular}

Berdasarkan tabel 6 dapat diketahui dari 45 responden mayoritas yang menjawab pencapaian program promotif pemberian ASI eksklusif tidak baik tetapi menilai kinerja tenaga kesehatan baik sebanyak 31 orang
$(68,9 \%)$, dan minioritas yang menjawab pencapaian program promotif pemberian ASI eksklusif baik dan menilai kinerja tenaga kesehatan baik sebanyak 14 orang $(31,1 \%)$, dan dari 7 responden mayoritas yang menilai pencapaian program promotifpemberian ASI eksklusif tidak baik dan kinerja tenaga kesehatan tidak baik sebanyak 7 orang $(50,0 \%)$, dan minoritas yang menjawab pencapaian program promotifpemberian ASI eksklusif baik tetapi kinerja tenaga kesehatan tidak baik sebanyak 7 orang $(50,0 \%)$.

\section{PEMBAHASAN}

3.5.1. Faktor-faktor yang berhubungan dengan pencapaian program promotif pemberian ASI eksklusif Berdasarkan Pekerjaan Ibu di Puskesmas Darussalam Medan Tahun 2019.

Hasil analisis bivariat diperoleh nilai $p$ value $=0,197$ ( $p$ value $>0,05)$ artinya Ho diterima, ini menunjukkan bahwa tidak ada hubungan yang signifikan antara pekerjaan ibu dengan pencapaian program promotif pemberian ASI eksklusif di Puskesmas Darussalam Tahun 2019.

Hasil penelitian Maghdawati,dkk (2016) penelitian ini tidak terdapat hubungan antara pekerjaan ibu dengan pencapaian program promotif pemberian ASI eksklusif, itu dikarenakan pendidikan dan pengetahuan ibu sangat rendah dan tidak terdapat hubungan antara pekerjaan dengan pemberian ASI eksklusif $p=0,668(p>0,06)$.

Menurut Teori Kemenkes (2015) Ibu yang bekerja selama 8 jam. berakibat ibu tidak mempunyai waktu cukup untuk menyusui anaknya. Keadaan tersebut mempengaruhi minimnya kesempatan untuk memberi ASI kepada bayi.

Menurut asumsi peneliti, hasil penelitian ini sesuai dengan teori yang ada, karena tidak ada hubungan apabila pekerjaan ibu terlalu banyak maka tidak ada hubungnnya terhadap program promotif dalam pemberian ASI eksklusif bagi bayi.

Berdasarkan hasil wawancara diketahui bahwa banyak responden yang beranggapan pekerjaan yang ibu lakukan dalam kehidupan sehari-hari tidak ada meskipun itu berat atau ringan tidak ada 
hubugannya terhadap pemberian ASI yang ia lakukan terhadap bayinya.

\subsubsection{Faktor-faktor yang} berhubungan dengan pencapaian program promotif pemberian ASI eksklusif Berdasarkan Pengetahuan Ibu di Puskesmas Darussalam Medan Tahun 2019.

Hasil analisis bivariat diperoleh nilai $p$ value $=0,033$ ( $p$ value $<0,05$ ) artinya Ho ditolak, ini menunjukkan bahwa ada hubungan antara pengetahuan ibu dengan pencapaian program promotifpemberian ASI eksklusif di Puskesmas Darussalam Tahun 2019.

Hasil penelitian Hartatik (2009), diperoleh bahwa ada hubungan antara pengetahuan ibu dengan pemberian ASI eksklusif $(p=0,028)$, ada hubungan antara sikap ibu dengan pencapaian program promotif pemberian ASI eksklusif $(p=0,004)$, akan tetapi hasil penelitian Haryati,dkk (2016) tidak sejalan dikarenakan tidak ada hubungan pengetahuan ibu dengan pencapaian program promotif pemberian ASI eksklusif pada bayi 0-6 bulan di Kelurahan Tambun Kecamatan Baolan Kabupaten Tolitoli dengan nilai $p=0,000$

Menurut Teori (Martini,2017), Pengetahuan merupakan salah satu faktor predisposisi yang menentukan perilaku kesehatan seseorang. Pengetahuan tersebut didapat melalui pendidikan formal, penyuluhan dan informasi dari media masa.

Menurut asumsi peneliti, hasil penelitian ini sesuai dengan teori yang ada, karena ada hubungan apabila pengetahuan ibu rendah maka berpengaruh terhadap pemberian ASI eksklusif bagi bayi.

Berdasarkan hasil wawancara diketahui bahwa banyak responden yang beranggapan pengetahuan ibu rendah cenderung memiliki prilaku yang kurang baik pula, sedangkan ibu dengan tingkat pengetahuan tinggi maka semakin besar kemungkinannya untuk memberikan ASI eksklusif kepada bayinya.

3.5.3. Faktor-faktor yang berhubungan dengan pencapaian program promotif pemberian ASI eksklusif Berdasarkan sikap Ibu di
Puskesmas Darussalam Medan Tahun 2019.

Hasil analisis bivariat diperoleh nilai $p$ value $=0,033$ ( $p$ value $<0,05$ ) artinya Ho ditolak, ini menunjukkan bahwa ada hubungan antara sikap ibu denganpencapaian program promotif pemberian ASI eksklusif di Puskesmas Darussalam Tahun 2019.

Hasil penelitian Nurleli,dkk (2017) dapat disimpulkan bahwa pendidikan erat hubungannya dengan pengetahuan, sikap dan tindakan pemberian ASI eksklusif sehingga semakin tinggi pendidikan, semakin baik baik pula pengetahuan, sikap dan tindakan pemberian ASI eksklusif, tetapi tidak sejalan dengan hasil penelitian Handayani (2011), hasil penelitian menggambarkan bahwa sebagian besar responden tidak memberikan ASI eksklusif pada bayinya $(90,6)$. Faktor predisposisi umur, pekerjaan, dan sikap tidak menunjukkan hubungan dengan prilaku pemberian ASI ekslusif, akan tetapi dari pendidikan di peroleh $p=$ value $(0,001)$.

Menurut Teori (Febriyanti dan Ernawati, 2014). Ibu yang menerima/memahami informasi dengan baik dan mempraktikannya maka akan memiliki sikap yang baik dan berpeluang baik dalam memberikan ASI eksklusif meskipun tingkat pendidikannya rendah .

Menurut asumsi peneliti, hasil penelitian ini sesuai dengan teori yang ada, karena ada hubungan sehingga dapat disimpulkan bahwa sikap memiliki hubungan dengan pendidikan. Dengan kata lain, semakin tinggi pendidikan semakin baik sikap dalam memberikan ASI eksklusif.

Berdasarkan hasil wawancara diketahui bahwa banyak responden yang beranggapan sikap yang ibu lakukan dalam kegiatan/aktivitas sehari-hari ada hubungannya terhadap pemberian ASI eksklusif .

\subsubsection{Faktor-faktor yang berhubungan dengan pencapaian program promotif pemberian ASI eksklusif Berdasarkan kinerja tenaga kesehatan di Puskesmas Darussalam Medan Tahun 2019.}

Hasil analisis bivariat diperoleh nilai $p$ value $=0,197$ ( $p$ value $>0,05)$ artinya Ho diterima, ini menunjukkan bahwa tidak 
ada hubungan yang signifikan antara kinerja tenaga kesehatan dengan pencapaian program promotif pemberian ASI eksklusif di Puskesmas Darussalam Tahun 2019.

Hasil penelitian Andriani,dkk (2016) menunjukkan perlu adanya konseling menyusui, sedangkan di Puskesmas Lumpatan belum tersedianya tim konseling ASI. Program ASI eksklusif di Puskesmas Lumpatan masih ditemukan kurangnya sarana dan prasarana. Dari hasil hasil penelitian Dewi, menunjukan bahwa sebagian besar belum melakukan pelayanan promotif, unsur input, SDM di FKTP belum ada yang memiliki petugas khusus untuk pelayanan promotif. Tidak ada FKTP yang mengalokasikan biaya untuk pelayanan promotif, sehingga dapat disimpulkan bahwa kinerja tenaga kesehatan dengan program promotif pemberian ASI eksklusif tidak memiliki hubungan.

Menurut Teori (Azriani dan Wasnidar, 2014) Tenaga Kesehatan juga berdampak terhadap pemberian ASI eksklusif. Dukungan petugas kesehatan sangat penting dalam mendorong tercapainya pemberian ASI eksklusif. Petugas kesehatan harus meyakinkan serta menjelaskan secara bijaksana kepada ibu tentang manfaat menyusui. Petugas kesehatan dapat memberikan dukungan mulai dari masa kehamilan yakni ketika ibu memeriksakan kehamilannya. Hal yang dapat dilakukan yakni memberikan pendidikan kesehatan dan membantu persiapan diri. Pendidikan kesehatan dapat berupa informasi informasi mengenai ASI eksklusif. Persiapan diri dapat berupa persiapan fisik, persiapan mental, serta persiapan pelaksanaan IMD. Persiapan fisik berupa gizi ibu, dan kebersihan payudara. Persiapan mental berupa upaya meningkatkan keyakinan dan memotivasi ibu untuk mendapatkan ASI eksklusif serta membantu persiapan pelaksanaan IMD. Pendampingan menyusui merupakan bentuk dukungan lain yang dapat diberikan oleh petugas kesehatan.

Menurut asumsi peneliti, hasil penelitian ini sesuai dengan teori yang ada, karena tidak ada hubungan apabila kinerja tenaga kesehatan sedikit maupun banyak maka tidak berpengaruh terhadap pencapaian program promotif dalam pemberian ASI eksklusif bagi bayi karena tidak adanya pengalokasiakan dana untuk program pemberian ASI eksklusif .

Berdasarkan hasil wawancara diketahui bahwa banyak responden yang beranggapan kinerja tenaga kesehatan ada hubungannya terhadappencapaian program promotif pemberian ASI eksklusif

\section{KESIMPULAN DAN SARAN Kesimpulan}

Berdasarkan penelitian yang telah dilakukan dapat disimpulkan sebagai berikut :

1. Tidak ada hubungan yang signifikan antara Pekerjaan Ibu dengan pencapaian program promotif pemberian ASIEsksklusif di Puskesmas Darussalam Medan Tahun 2019.

2. Ada hubungan yang signifikan antara Pengetahuan denganpencapaian program promotif pemberian ASI Esksklusif di Puskesmas Darussalam Medan Tahun 2019.

3. Ada hubungan yang signifikan antara Sikap Ibu dengan pencapaian program promotifpemberian ASI Esksklusif di Puskesmas Darussalam Medan Tahun 2019.

4. Tidak ada hubungan yang signifikan antara Kinerja Tenaga Kesehatan dengan pencapaian program promotifpemberian ASI Esksklusif di Puskesmas Darussalam Medan Tahun 2019.

\section{Saran}

1. Bagi Responden

Perlu peran aktif dalam pelaksanaan pemberian ASI eksklusif agar dapat meningkatkan frekuensi pencapaian target pelaksanaan program promotif ASI ekslusif di Puskesmas Darussalam Medan.

2. Puskesmas

Bagi Puskesmas Darussalam Medan disarankan agar kerjasama melakukan promosi kesehatan tentang pentingnya memberikan ASI eksklusif bagi bayi untuk mengacu pada sepuluh langkah menuju keberhasilan menyusui. 
3. Peneliti selanjutnya.

Bagi peneliti selanjutnya disarankan untuk dapat mengembangkan penelitian ini dengan rancangan penelitian serta analisis yang berbeda untuk memperoleh hasil yang baik setiap tahunnya.

\section{DAFTAR PUSTAKA}

Anggraeni, Wulan,Indah. $\quad 20$ Penyusun Proposal Skrif Universitas Prima Indonesia Medan.

Dewi, Kumala, Ratih, dkk .201 Dalam Asri A. Analis Pelaksanaan PelayananPromotif dan Preventif dalam Era JaminanKesehatan Nasional (JKN) di PuskesmasBelawan". Skripsi. Medan; 2014.

Dinas Kesehatan Provinsi Sumatera Utara.2013.profil Kesehatan Sumatera Utara Tahun 2013. Medan

Indonesia. Peraturan Menteri Kesehatan Republik Indonesia No.71 Tahun 2013 Tentang Pelayanan Kesehatan Pada Jaminan Kesehatan Nasional. Jakarta; 2013.

Kementerian Kesehatan RI. 2015. Dukung Ibu Bekerja Beri ASI Eksklusif. www.depkes.go.id diakses pada tanggal 26 September 2017.

Korompis, C.E, Grace.dr. 2016. Organisasi \& Manajemen

Maryunani, Anik. 2015. Inisiasi Menyusu Dini, ASI Eksklusif dan Manjemen Laktasi. Jakarta: CV. Trans Info Media.

Notoatmodjo, S. 2013. Metodologi Penelitian Kesehatan. Rineka Cipta: Jakarta.

Peraturan Menteri Kesehatan RI. Nomor 75 Tahun 2014.Tentang Pusat Kesehatan Masyarakat. http://www.depkes.go.id/resourc es/download/peraturan/PMK-No75-Th-2014-ttg-

Puskesmas.pdfdiakses pada tanggal 16 November 2018

Profil Kesehatan Indonesia.2016. http://www.depkes.go.id/resourc es/download/pusdatin/profilkesehatan-indonesia/Profil-
Kesehatan-Indonesia-

2016.pdfdiakses pada tanggal 17 November 2018.

Profil UPT Puskesmas Darussallam.Medan.2018.

Putri A.Y. 2014. Hubungan Pekerjaan Ibu dengan Keberhasilan Pemberian ASI eksklusif pada Anak di Posyandu Bina Putra Tirto Triharjo Pandak Bantul Yogyakarta. Naskah Publikasi.

Republik Indonesia. 2013. Peraturan Menteri Kesehatan No. 15 Tahun 2013 tentang Tata Cara Penyediaan Fasilitas Khusus Menyusui Dan/ Atau Memerah Air Susu Ibu. Jakarta.

Sensasi,Yayi, Rizki.2018. PenyusunProposal Skripsi. Universitas Prima Indonesia Medan

Setia.2018. Hubungan Pekerjaan Dan Pendidikan Ibu Dengan Pemberian ASI Eksklusif Di Wilayah Kerja Puskesmas Hinai Kiri Tahun 2017.https://media.neliti.com/me dia/publications/234018-

hubungan-pekerjaan-dan pendidikan-ibu-de-e6545e26.pdf. Jurnal Kesehatan Masyarakat.Sekolah Tinggi Ilmu Kesehatan Putra Abadi Langkat, J। Mayjen Suprapto No.10Stabat,Langkat,SUMUT.Vol 5(3): 1-9. Diakses pada tanggal 24 Desember 2018.

Sugiyono, 2018. Metodologi Penelitian Kuantitatif, Kualitatif dan R\&D, Alfabeta, Bandung

Supratman D. Upaya Promotif danPreventif yang Masih Terabaikan di Era JKN. Tidak Diterbitkan. IAKMI. Jakarta; 2015.

Triwibowo, Cecep, dkk. 2017. Pengantar Dasar IImu Kesehatan Masyarakat. Yogyakarta: Nuha Medika.

Walyani, Siwi, Elisabeth, dkk. 2017. Asuhan Kebidanan Masa Nifas \& Menyusui. Yogyakarta: PT. Pustaka Baru.

WHO dalam (Nurleli,dkk). 2017. Hubungan Pengetahuan Dan Sikap Ibu Dengan Tindakan Pemberian Asi Eksklusif Di Puskesmas Rambung Kecamatan 
Binjai Selatan Kota Binjai Tahun 2017.http://jurnal.kesdammedan .ac.id/index.php/27Mei2016/articl e/download/16/15. Jurnal Kesehatan Masyarakat .Vol3(5):41-45. Diakses pada tanggal 24 Desember 2018. 